\title{
A Study on Consumer Buying Behavior towards Branded Apparels at Pandemic Times.
}

1. Basaveshwar Dhannurkar Assistant Professor and Research Scholar Faculty of Business Studies Sharnbasva University Kalaburagi, Karnataka bassu6060@gmail.com

2.Dr. B S Hugar Professor \& Chairman MBA Programme Faculty of Business Studies Sharanbasva University Kalaburagi, Karnataka bshugar039@gmail.co

\begin{abstract}
$\underline{\text { ABSTRACT }}$
COVID-19 has slowed down sales for businesses across various industries. Especially the apparel brand lies under the non-essentials category. But as the government starts to relax the lockdowns and restrictions, it's time to get back to business. Although this time, apparel businesses need to be aware of how their consumer's behavior has evolved during this period. In this article, I am trying to bring what we have learned about the change in consumer behavior and how apparel brand Company can adapt it.
\end{abstract}

\section{Key word - Apparel, Consumer's behavior, Covid-19, Pandemic}

\section{INTRODUCATION}

The crisis created by the corona virus pandemic hit the apparel industry especially hard. Online shopping surged, but not enough to erase the damage done by store closings and economic worries, which caused people to curtail spending on nonessential goods. Industry revenue this year could drop by more than one-third.

Country is now beginning to reopen its economies, and companies and people are gradually returning to work. But fashion won't - and shouldn't — return to what it was. The behaviors, preferences, and shifts in mindset that people have adopted during the pandemic will lead to permanent changes, including bifurcated spending, accelerated adoption of e-commerce, and increased demand for purpose-driven brands and sustainable fashion. 
For apparel brands, the trends and the dramatic drop in sales will contribute to substantial retail overcapacity. It will lead companies to adopt a new shape of P\&L, accelerate the shift to digital and omnichannel distribution, embrace data analytics for decision making, and, for those with cash, pursue M\&As when they have the opportunity. The sooner brands come to terms with this new reality, the sooner they can take the steps needed to rebound and succeed. It is time for a reset, not a restart.

While it's too early to quantify COVID-19's toll on the apparel fashion sector, the pandemic has certainly shaken some of the industry's foundations below some of my research finding towards change in customer behavior at pandemic towards apparel industry

\section{Understanding and Adapting to the new practice to attract consumer}

\section{Consumers are choosing to make more online purchases}

E-commerce has been growing at a rapid pace over the last few years. The pandemic only accelerated the adoption across all industries. Consumers now choose online shopping for even their day-to-day necessities to avoid stepping into public spaces.

Apparel brands now need to consider going online with their products. It will give them the ability to reach out to their existing customers and attract new ones by promoting a 'safer' way to shop that lets them experience in-store shopping, online. According to the Economic Times, Indian consumers may shift to only online shopping in the next few months. .

\section{Consumers are seeking bulk discounts for volume purchases}

The new-age consumer is more informed than ever. They are aware of the possible limitations on the availability of items and delivery delays. That's why you'll see this new consumer choose to buy certain products in bulk. So they can remain prepared for days to come by making the purchase once. But at the same time, they're also looking for brands that can offer those discounts on bulk purchases so that they can do the same on other items they need.

Apparel brands will need to understand their customers better and which of their products in the inventory can be sold in bulk. Creating bundles of fashion wear is a good idea to make more 
sales right now, but so is keeping in mind what kind of fashion wear the consumer is more likely to put to use as of today spending more time on their mobile devices. According to Social Media Today, people are spending 20\% more time in apps alone. Apparel retailers need to take this consumer behavior into account to be able to reach them where they are the most active. It's a good idea to move past just mobile-web ready online stores to setting up native apps for your store. The easier it is for a consumer to browse through your products, create wish lists and make purchases, the higher will be your conversions. Retailers that have adapted to this change have seen a spike in their sales and revenue by a whopping $26 \%$.

\section{Consumers prefer making online payments}

The want of limiting contact with the outside world has increased the number of consumers who choose to make online payments for their orders. You can see a clear drift from opting for COD (cash on delivery) to looking for online payment modes like Net banking, digital wallets and more.

Apparel businesses will need to take into account the different types of shoppers their online store will get. It is important to now offer multiple payment modes to consumers to ensure you don't lose out on sales.

A good idea is to start by analyzing what existing customers chose for making online payments. Remember, the idea is to offer popular payment methods in your target area.

\section{Consumers are demanding no-contact delivery}

Continuing on the consumer's need to limit contact with delivery personnel, offering the right delivery mode has also become important to survive the COVID-19 slowdown. If store has been offering regular delivery methods that don't boast of the no-contact and doorstep delivery, We will see a lot of consumers walking away.

As a Apparel brand, we need to ensure that you have a hygiene page up on your store. This page should share how you're following all regulations to ensure safe delivery of orders. Including a line or two on your packaging process can get you more brownie points from consumers. 
Another delivery method that retailers can now consider is buying online and pick-up from the store. This gives the consumer the flexibility to choose when they want to pick up their order and mental satisfaction of how the number of people in contact with their order gets reduced

\section{Consumers want to engage with brands that support a cause}

These are difficult times and the new-age consumer is choosing to do their bit in giving back to society. There has been an increase in the number of people that choose to interact with a brand or buy from them after seeing that they support a cause that is commonly shared. More than discounts, 'cause marketing' is what will drive more sales for online retailers. Apparel brands will need to look into what their target audience cares about the most. Then we need to identify how you can join them in their efforts to add value to those in need.

\section{Consumers are seeking familiarity}

These are uncertain times and being introduced to something new isn't exactly what consumers are looking for. A study by bloom reach suggests that consumers are now looking for familiarity and nostalgia. They want to purchase items that remind them of their childhood or the happier times as we call it.

While fashion trends can't really have a nostalgic throwback, you can change your messaging slightly to tap into the consumer emotion. For instance, run a campaign that asks them about their favorite age-old fashion trend. Give them a chance to get featured on your feed and you'll see how word-of-mouth starts to drive more people to your store.

\section{Consumers are focusing on buying essentials}

Due to Covid- 19 time Consumers are much focusing on essential buying, Their spending habits have been altering week by week. While some industries have seen an upsurge in the number of orders being placed online especially with essentials and even apparels items

It's not just consumer behavior that your fashion and apparel brand needs to take into consideration. We also need to identify what products are consumers looking for and using. The closer you are to selling what your consumers need, the more likely they are to purchase from your store. 


\section{Consumers are seeking an immersive experience}

With the rise in mobile app usage and technology, consumers are also expecting online retailers to offer an interactive platform. Since they're limited in ways to get a look and feel of a product, they expect brands to be able to offer them as much information so as to make an informed purchase.

With smart apps, your store can offer virtual try-ons to consumers on products. This will help them get an understanding of how the product looks on them. On the flip side, it will help your store reduce the number of returns and refunds.

\section{Consumers want to plan their budgets better}

No one knows what the next week is going to look like. That's why consumers are being careful about their spending habits. While a lot of them are focusing on purchasing only the absolute essentials, there are others indulging in non-essentials but in a limited manner. They want to save on their resources for tougher times.

Fashion and apparel retailers that go online should consider offering the ability to pay partially. Similar to how you can set up easy EMIs for a purchase you make. Adding this to the offered payment methods is like showing consumers you care about their resources as much.

\section{CONCLUSION}

Yes, it is difficult to reach out to consumers who are still paranoid about coming to apparel brand store but it is not impossible either. The only way to survive the Covid-19 pandemic is to make your brand omnipresent by offering a digital presence along with the physical outlets that please and serve customers in the best and safest way as possible.

Since the future of brick and mortar shops is very vague given the current situation outside the safety of your homes, making your brand digital is the need of the hour. So, if you are still struggling to find a good fashion ecommerce mobile app builder, seeking the help of the topnotch Magen to multivendor ecommerce app development company like Mob commerce can be your knight in shining arm our to help you go digital. 


\section{RAFERANCE}

Queiroz, M. M., Ivanov, D., Dolgui, A., \& Fosso Wamba, S. (2020). Impacts of epidemic outbreaks on supply chains: mapping a research agenda amid the COVID-19 pandemic through a structured literature review. In Annals of Operations Research (Issue 0123456789). Springer US.

$>$ Rowland, F. (2011). The Filter Bubble: What the Internet is Hiding from You (review). Portal Libraries and the Academy, 11(4), 1009-1011.

> Thakur, V., \& Jain, A. (2020). COVID 2019-suicides: A global psychological pandemic. Brain, Behavior, and Immunity, 88(xxxx), 952-953.

$>$ Trong, L., \& Tran, T. (2020). Managing the effectiveness of e-commerce platforms in a pandemic. January.

Valaskova, K., Kramarova, K., \& Bartosova, V. (2015). Multi Criteria Models Used in Slovak Consumer Market for Business Decision Making. Procedia Economics and Finance, 26(15), 174-182 